\title{
Analysis of the effects of essential oils on airborne bacteria in a customized bio-clean room
}

\author{
HYUN YANG ${ }^{1}$, TAE-HYOUNG KOO ${ }^{1}$, CHANG-YOUNG HONG $^{2}$, IN-GYU CHOI $^{2}$ and EUI-BAE JEUNG ${ }^{1}$ \\ ${ }^{1}$ Laboratory of Veterinary Biochemistry and Molecular Biology, College of Veterinary Medicine, \\ Chungbuk National University, Cheongju, Chungbuk 361-763; ${ }^{2}$ Department of Wood Chemistry, \\ Department of Forest Sciences, College of Agriculture and Life Sciences, Seoul National University, \\ Seoul 151-921, Republic of Korea
}

Received February 20, 2012; Accepted June 20, 2012

DOI: $10.3892 / \mathrm{mmr} .2012 .972$

\begin{abstract}
Essential oils have a sedative effect on stress, and are also known to have antibiotic and anti-carcinogenic effects. These compounds have long been used as natural microbial agents, and have recently been added to a number of pharmaceutical, food and cosmetic products. Controlling the exposure to allergens and pathogens are important factors for the treatment of allergy, and potentially reducing the risk of sensitization and infection. Low humidity, at levels under $35 \%$, may affect human comfort and health during the winter. Patients and other individuals require optimal humidification to maintain a moisturized respiratory tract necessary for protecting against bacterial infection. We designed an analytical system to examine the effects of aromatherapeutic essential oils on airborne bacteria. The antibacterial activities of essential oils were assayed using agar plate air-sampling methods. A bacterial suspension was sprayed into a bio-clean room through the upper holes using a spray gun. Free-floating airborne bacteria were collected from the bio-clean room (blank) in blood agar plates for $10 \mathrm{sec}$ using an air sampler. Three different concentrations of essential oils $(0.0005,0.005$ and $0.05 \mathrm{ppm}$ ) were then sprayed into the bio-clean room for $5 \mathrm{~min}$. Free-floating airborne bacteria were collected every $10 \mathrm{~min}$ for $10 \mathrm{sec}$ each. Treatment with $0.0005 \mathrm{ppm}$ essential oils inhibited the growth of colonies; this effect appeared to persist after $60 \mathrm{~min}$. Decreased bacterial colony growth was more apparent in the presence of $0.005 \mathrm{ppm}$ and $0.05 \mathrm{ppm}$ essential oils than $0.0005 \mathrm{ppm}$. These effects were observed after 60 min compared to the control (distilled water). These results indicate that essential oils are able to inhibit the growth of airborne bacteria.
\end{abstract}

Correspondence to: Dr Eui-Bae Jeung, Laboratory of Veterinary Biochemistry and Molecular Biology, College of Veterinary Medicine, Chungbuk National University, 48 Gaeshin-dong Heungduk-gu, Cheongju, Chungbuk 361-763, Republic of Korea E-mail: ebjeung@chungbuk.ac.kr

Key words: humidifier disinfectants, essential oils, airborne bacteria

\section{Introduction}

Essential oils have a sedative effect that decreases stress, and are also used as antibiotic and anti-carcinogenic agents $(1,2)$. These compounds have long been used as natural microbial agents. Recently, essential oils were added to a number of pharmaceutical, food and cosmetic products as they effectively inhibit the growth of a wide range of microorganisms. Their broad spectrum of in vitro antimicrobial activities is attributed to their high content of phenolic derivatives (3). In a recent study, plant extracts were examined and their use in foods as natural antioxidants was proposed $(4,5)$. Essential oils have been used for aromatherapy since 18,000 B.C. (1). Aromatherapy was performed to cure sickness and fatigue in the Stone Age. In the modern era, essential oils are increasingly being used to improve quality of life and relieve various symptoms in patients. However, studies evaluating the effects of aromatherapeutic essential oils on airborne bacteria are scarce. The majority of individuals usually spend $85 \%$ of their time indoors. In general, three methods are suggested for improving indoor air quality: source control, increased ventilation and air cleaning. Source control is often ungovernable in metropolitan areas, including Seoul, Korea, while increased ventilation may transport more pollutants from the outdoor environment $(6,7)$. Therefore, air cleaning remains the most feasible option for improving indoor air quality. Air cleaners are considered to be an effective means of maintaining a clean indoor environment. General vacuumed air cleaners are used for preventing asthma and allergic disease (8). However, vacuum cleaners and the act of vacuuming can release and resuspend dust and allergens in the air, thereby leading to increased exposure $(9,10)$. Allergenic and antigenic bacteria collected with dust by vacuums can also serve as reservoirs of infectious agents that remain in vacuum cleaners (11).

Potentially harmful bacteria are all around us. The acts of talking, coughing, sneezing and breathing generate aerosolized droplets of moisture containing bacteria. Indoors, the airborne circulation of pathogens potentially promotes infections in our body, particularly in hospitals. For example, methicillin-resistant Staphylococcus aureus (MRSA) can be transmitted in an aerosolized form via the respiratory tract $(12,13)$. Controlling the exposure to allergens and pathogens is therefore important 
for the symptomatic treatment of allergy, and potentially reducing the risk of sensitization and infection. Low humidity, at levels under 35\%, may affect human comfort and health during the winter. When humidity is low, decreased comfort and increased risk of allergies, asthma, attacks on the immune system and mortality are observed. However, general humidifiers are also associated with risk of infection of the respiratory tract due to pathogens and allergens.

In the present study, we designed a system to analyze the effects of aromatherapeutic essential oils on airborne bacteria. The aim of our study was to determine whether the anti-airborne bacterial effects of essential oils are able to significantly improve indoor air quality.

\section{Materials and methods}

Experimental microorganisms. To examine the anti-airborne bacterial activity of each essential oil, six bacterial strains were obtained from the Culture Collection of Antimicrobial Resistant Microbes (Seoul, Korea). The anti-airborne bacterial effect of essential oils distilled by ALDIX (Gyeong-Gi, Korea) was evaluated. These included Streptococcus pyogenes (CCARM 0032), Streptococcus pneumonia (CCARM 4001), Klebsiella pneumonia (CCARM 0085), Neisseria meningitidis (CCARM 0073), Hemophilus influenzae (CCARM 9001) and Escherichia coli (CCARM 0010). The strains were cultured on blood agar plates (BAP; Hanil Komed Co., Gyeong-Gi, Korea) at $37^{\circ} \mathrm{C}$ in a humidified atmosphere of $95 \% \mathrm{O}_{2}$ and $5 \% \mathrm{CO}_{2}$. The suspended bacteria were collected $12 \mathrm{~h}$ after spreading onto the BAP and the bacterial concentration was determined using a spectrophotometer (Perkin-Elmer Co., Wellesley, MA, USA) at an absorbance of $590 \mathrm{~nm}$.

Bio-clean room. The bio-clean room used for this study comprised a non-interrupted acrylic plate, a Hypalon ${ }^{\circledR}$ glove box system (Innovative Technology Inc., Amesbury, MA, USA), a stainless steel frame, a pass box and a $6 \mathrm{~W}$ ultraviolet (UV) germicidal lamp (Sankyo Denki, Kanagawa, Japan), and contained extra ventilation holes (Fig. 1). The space was sealed with eco-silicon (LC-707; Lien Ching Enterprise Co., Ltd., Chungbuk, Korea) on each side. Anti-airborne bacterial activities were measured using the agar plate air-sampling methods with an air sampler (LGD; LD-P150, Seoul, Korea). The exterior and interior of the bio-clean room was cleaned using de-mineralized water and dried prior to testing following UV sterilization for $6 \mathrm{~h}$. The volume of the customized bio-clean room was $9.6 \mathrm{~m}^{3}$ (width, $200 \mathrm{~mm}$; length, $200 \mathrm{~mm}$; height, $240 \mathrm{~mm}$ ), and it was placed in a temperature- and humiditycontrolled room.

Anti-airborne bacterial activity assay. Bacterial cells were centrifuged at $2700 \mathrm{rpm}$ for $10 \mathrm{~min}$, washed with distilled water and resuspended in distilled water at a concentration of $10^{6}$ cells per $\mathrm{ml}$. The bacterial cell concentration was determined assuming an optical density of 1.0 at $540 \mathrm{~nm}$ was equivalent to $\sim 10^{9}$ cells per $\mathrm{ml}$ (14). Anti-airborne bacterial activities of the essential oils were assayed using agar plate air-sampling methods according to the (Merck, Darmstadt, Germany) manufacturer's instructions. A bacterial suspension

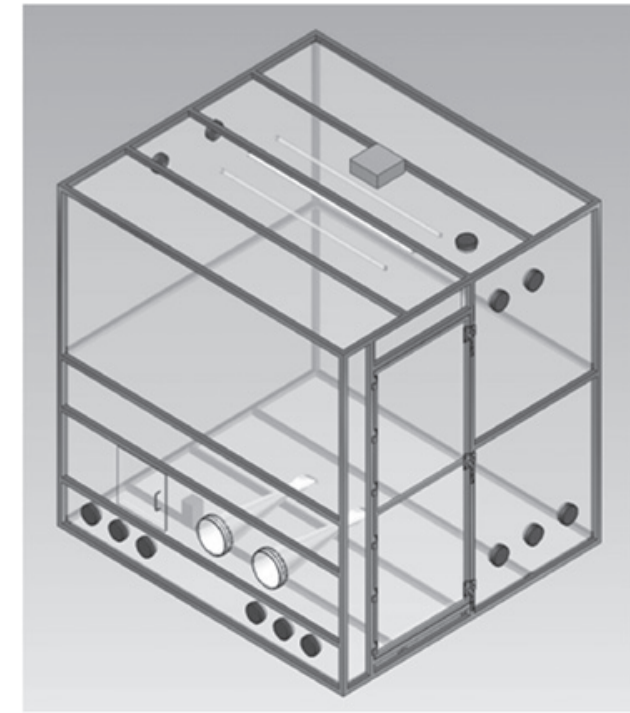

Figure 1. Schematic diagram of the bio-clean room.

was sprayed into the bio-clean room through the upper holes for 5 min using a spray gun (Dae-Won; DW-3; nozzle size, $0.5 \mathrm{~mm}$; Gyeong-Sang, Korea). The aerosolized bacteria were allowed to stabilize for $5 \mathrm{~min}$, and were then collected from the air of the bio-clean room (blank) into BAPs for $10 \mathrm{sec}$ with an air sampler. Three different concentrations of essential oils $(0.0005,0.005$ and $0.05 \mathrm{ppm})$ were sprayed into the bio-clean room for $5 \mathrm{~min}$, and the airborne bacteria were collected every $10 \mathrm{~min}$ for $10 \mathrm{sec}$. The BAPs were sealed and incubated overnight at $37^{\circ} \mathrm{C}$. After $12 \mathrm{~h}$, the resulting bacterial colonies were counted using a light box (Picker International, Cleveland, OH, USA) to analyze the decreasing concentrations of the airborne bacteria.

Data analysis. Data were presented as the mean \pm standard error of mean (SEM) and were analyzed by a one-way analysis of variance (ANOVA) test followed by a Tukey's multiple comparison test. Statistical analysis was performed using Prism Graph Pad (version 4.0; GraphPad Software Inc., San Diego, CA, USA). $\mathrm{P}<0.05$ was considered to indicate a statistically significant difference.

\section{Results}

Anti-airborne bacterial activities of essential oils. The effects of three concentrations of essential oils on airborne bacteria are shown in Table I. Treatment with essential oils inhibited the growth of airborne bacteria. The growth of airborne bacterial colonies on the BAPs were decreased in a time-dependent manner for the control (distilled water spray).

Streptococcus pyogenes. In the presence of $0.0005 \mathrm{ppm}$ essential oils, colony growth was clearly reduced at $50 \mathrm{~min}$, an effect that persisted for $60 \mathrm{~min}$. This decrease in the colony growth rate was more apparent in the presence of 0.005 and $0.05 \mathrm{ppm}$ essential oils compared to $0.0005 \mathrm{ppm}$. In the presence of 0.005 and $0.05 \mathrm{ppm}$ essential oils, colony growth was significantly decreased at 40 or $20 \mathrm{~min}$, respectively. As shown 
A
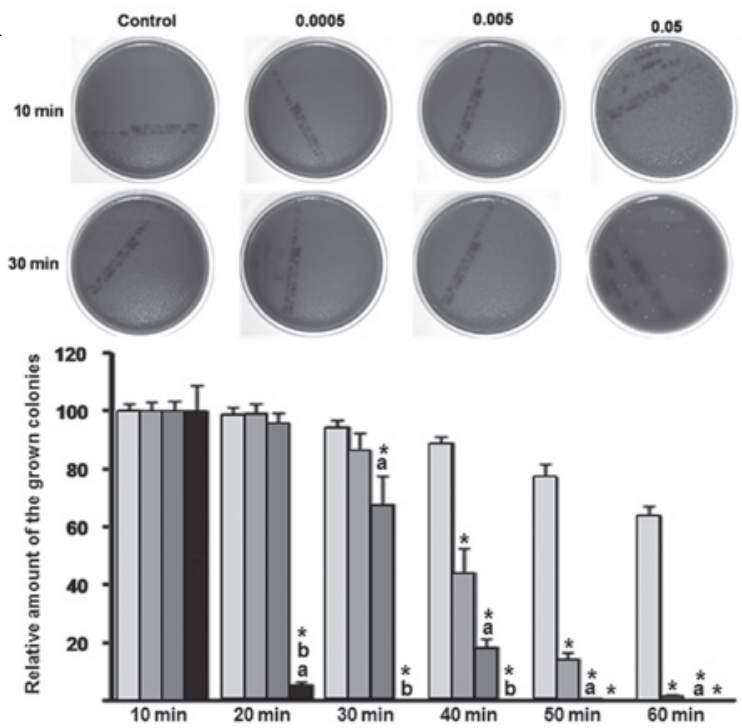

C
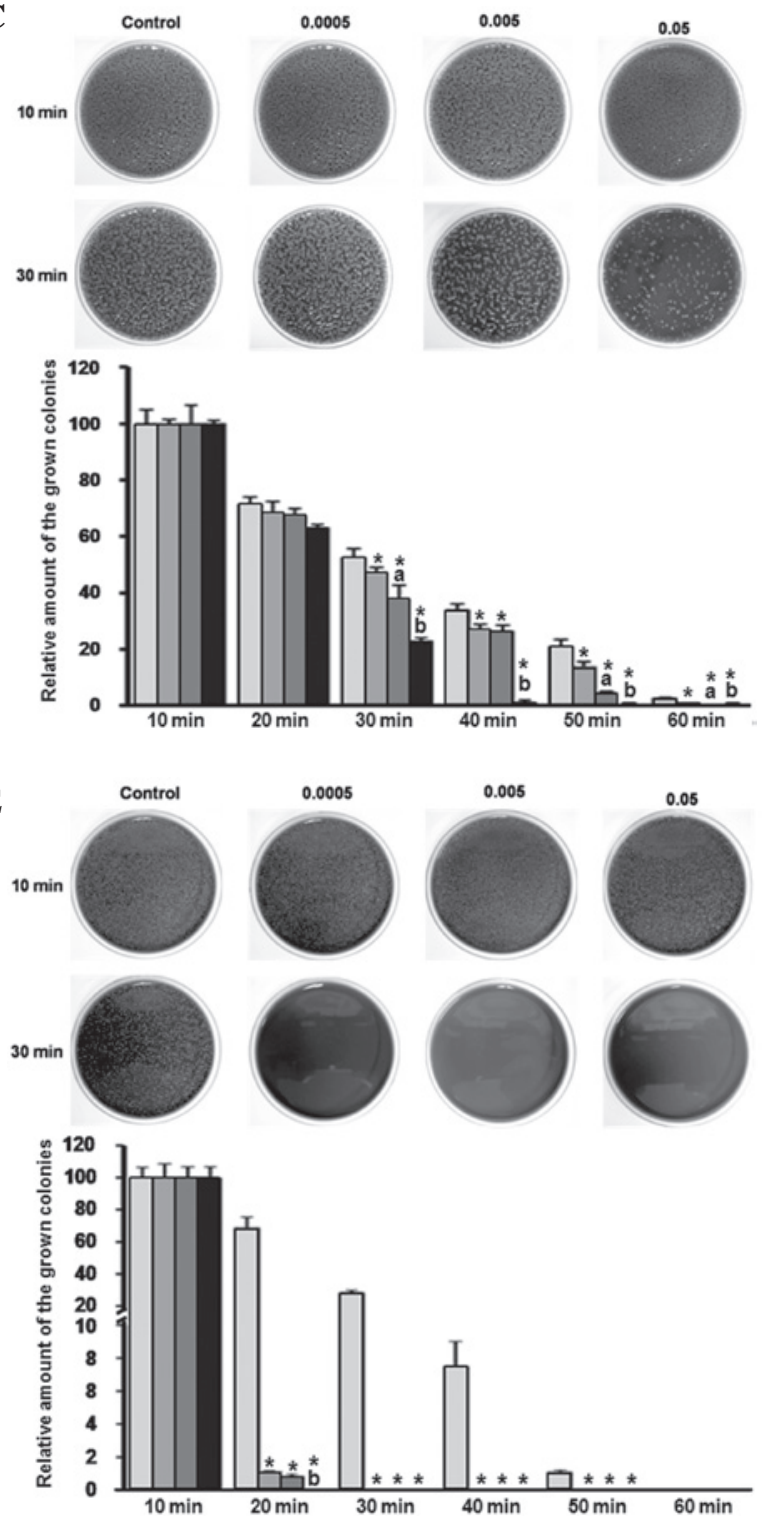

B
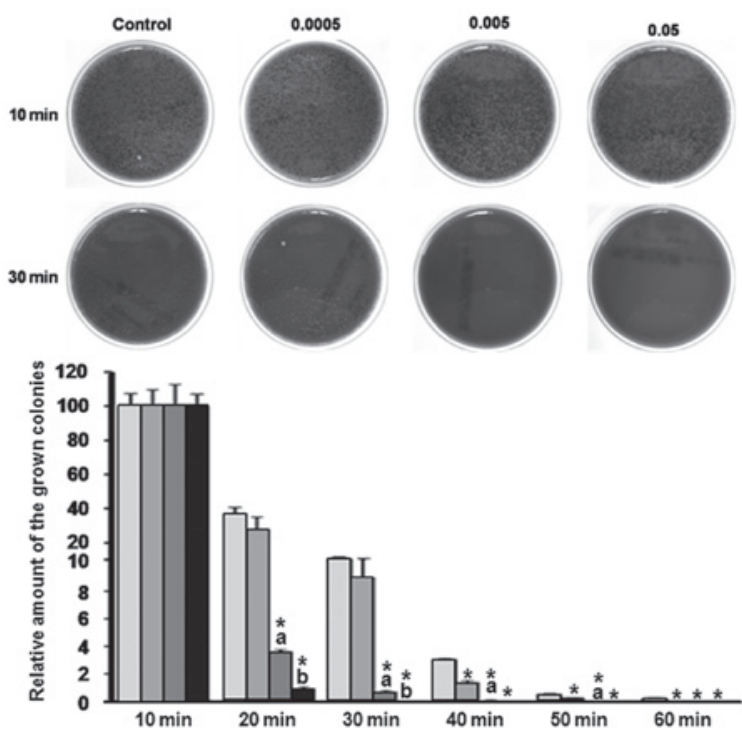

D
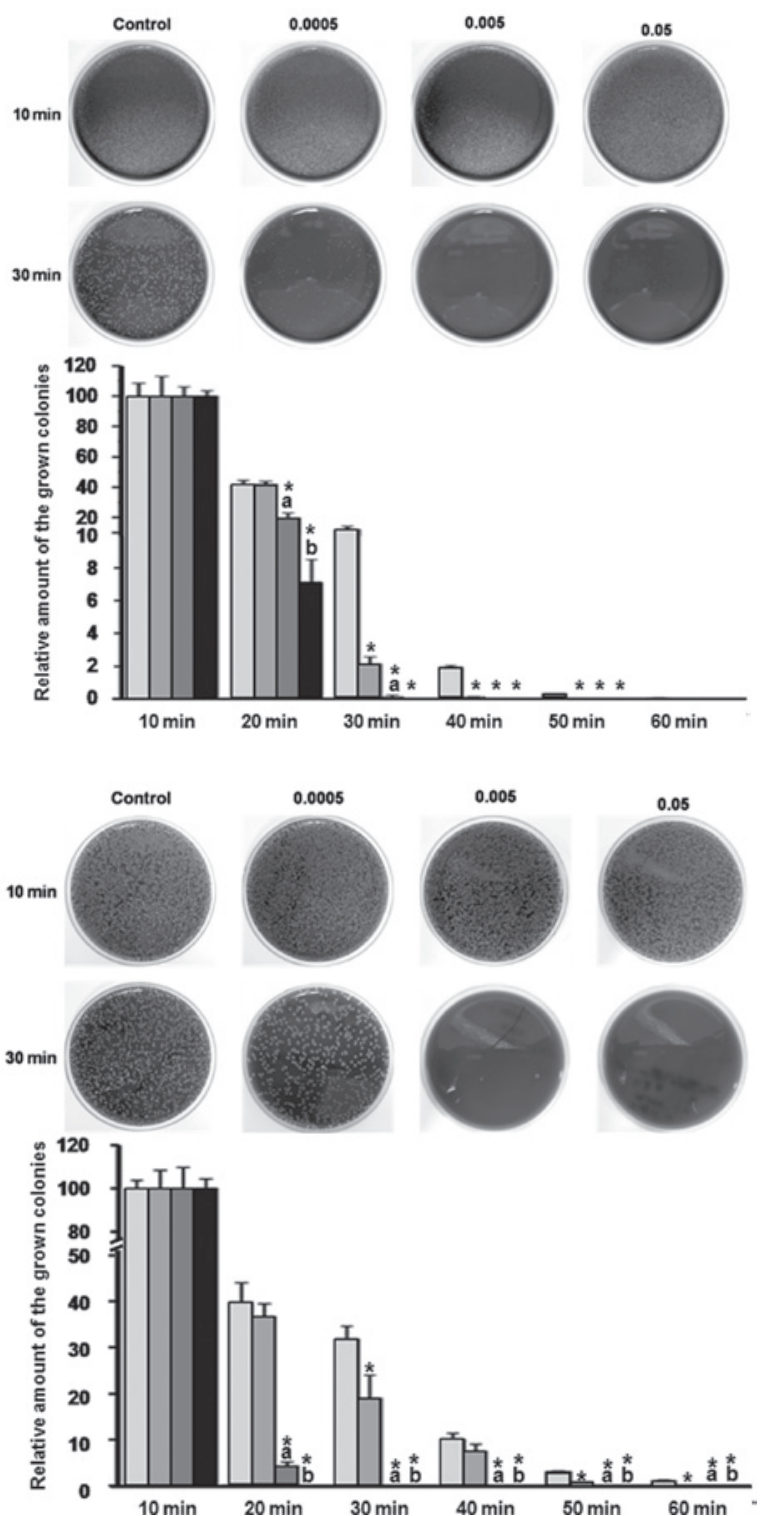

Figure 2. Anti-airborne bacterial activities of essential oils. Essential oils were administered at three concentrations $(0.0005,0.005$ and 0.05 ppm). Distilled water was administered as the control. Airborne bacterial cells were first collected at 10 min (without essential oil, blank). (A) Streptococcus pyogenes, (B) Streptococcus pneumonia, (C) Klebsiella pneumonia, (D) Neisseria meningitidis, (E) Hemophilus influenzae, (F) Escherichia coli are shown at 10-60 min (with essential oils). Experiments were performed in triplicate. ${ }^{*} \mathrm{P}<0.05$ indicated a significant difference in the decreased rate of colony growth compared to the control; ${ }^{\mathrm{a}} \mathrm{P}<0.05$ vs. $0.0005 \mathrm{ppm} ;{ }^{\mathrm{b}} \mathrm{P}<0.05$ vs. $0.005 \mathrm{ppm}$. 
Table I. Number of colonies grown in the air sampled blood agar plates.

\begin{tabular}{|c|c|c|c|c|c|c|c|}
\hline \multirow[b]{2}{*}{ Bacteria } & \multirow{2}{*}{$\begin{array}{c}\text { Essential oils } \\
\text { treatment }\end{array}$} & \multicolumn{6}{|c|}{ No. of colonies collected after 10 min intervals (mean \pm SEM) } \\
\hline & & $10 \mathrm{~min}$ & $20 \mathrm{~min}$ & $30 \mathrm{~min}$ & $40 \mathrm{~min}$ & $50 \mathrm{~min}$ & $60 \mathrm{~min}$ \\
\hline \multirow[t]{4}{*}{ E. coli } & Control & $4300 \pm 152$ & $1715 \pm 177$ & $820 \pm 119$ & $435 \pm 52$ & $131 \pm 10$ & $51 \pm 5$ \\
\hline & $0.0005 \mathrm{ppm}$ & $5100 \pm 430$ & $1875 \pm 137$ & $1625 \pm 247$ & $390 \pm 72$ & $51 \pm 1$ & $5 \pm 3$ \\
\hline & $0.005 \mathrm{ppm}$ & $4475 \pm 434$ & $200 \pm 30$ & $1 \pm 1$ & None & None & None \\
\hline & $0.05 \mathrm{ppm}$ & $3960 \pm 176$ & $1 \pm 1$ & None & None & None & None \\
\hline \multirow[t]{4}{*}{ K. pneu } & Control & $2565 \pm 122$ & $1835 \pm 63$ & $1345 \pm 80$ & $870 \pm 54$ & $535 \pm 63$ & $68 \pm 5$ \\
\hline & $0.0005 \mathrm{ppm}$ & $2690 \pm 42$ & $1845 \pm 104$ & $1275 \pm 40$ & $730 \pm 41$ & $370 \pm 45$ & $35 \pm 6$ \\
\hline & $0.005 \mathrm{ppm}$ & $2225 \pm 145$ & $1495 \pm 57$ & $840 \pm 108$ & $590 \pm 42$ & $105 \pm 10$ & $1 \pm 1$ \\
\hline & $0.05 \mathrm{ppm}$ & $2610 \pm 214$ & $1645 \pm 132$ & $600 \pm 75$ & $28 \pm 7$ & $1 \pm 1$ & None \\
\hline \multirow[t]{4}{*}{ H. influ } & Control & $12235 \pm 790$ & $8430 \pm 804$ & $3470 \pm 210$ & $920 \pm 181$ & $137 \pm 11$ & None \\
\hline & $0.0005 \mathrm{ppm}$ & $9780 \pm 833$ & $113 \pm 3$ & None & None & None & None \\
\hline & $0.005 \mathrm{ppm}$ & $11235 \pm 757$ & $98 \pm 12$ & None & None & None & None \\
\hline & $0.05 \mathrm{ppm}$ & $9445 \pm 645$ & None & None & None & None & None \\
\hline \multirow[t]{4}{*}{ S. pneu } & Control & $6845 \pm 510$ & $2520 \pm 269$ & $617 \pm 31$ & $209 \pm 6$ & $37 \pm 3$ & $16 \pm 2$ \\
\hline & $0.0005 \mathrm{ppm}$ & $6800 \pm 659$ & $1905 \pm 483$ & $760 \pm 108$ & $94 \pm 9$ & $17 \pm 2$ & None \\
\hline & $0.005 \mathrm{ppm}$ & $3485 \pm 446$ & $126 \pm 5$ & $25 \pm 3$ & $2 \pm 2$ & $1 \pm 1$ & None \\
\hline & $0.05 \mathrm{ppm}$ & $3950 \pm 281$ & $37 \pm 5$ & None & None & None & None \\
\hline \multirow[t]{4}{*}{ S. pyo } & Control & $10605 \pm 232$ & $10475 \pm 233$ & $10015 \pm 225$ & $9390 \pm 233$ & $8175 \pm 464$ & $6755 \pm 326$ \\
\hline & $0.0005 \mathrm{ppm}$ & $10500 \pm 293$ & $10425 \pm 301$ & $9055 \pm 623$ & $4620 \pm 870$ & $1520 \pm 185$ & $176 \pm 31$ \\
\hline & $0.005 \mathrm{ppm}$ & $8950 \pm 283$ & $8560 \pm 304$ & $6050 \pm 874$ & $1650 \pm 232$ & $74 \pm 5$ & $15 \pm 4$ \\
\hline & $0.05 \mathrm{ppm}$ & $4935 \pm 418$ & $271 \pm 43$ & $27 \pm 3$ & $7 \pm 4$ & $2 \pm 2$ & $1 \pm 1$ \\
\hline \multirow[t]{4}{*}{ N.meni } & Control & $13240 \pm 1130$ & $5490 \pm 381$ & $1630 \pm 223$ & $256 \pm 14$ & $42 \pm 1$ & $6 \pm 2$ \\
\hline & $0.0005 \mathrm{ppm}$ & $12770 \pm 1638$ & $5360 \pm 227$ & $275 \pm 52$ & $15 \pm 3$ & None & None \\
\hline & $0.005 \mathrm{ppm}$ & $13450 \pm 786$ & $2695 \pm 410$ & $19 \pm 11$ & None & None & None \\
\hline & $0.05 \mathrm{ppm}$ & $11720 \pm 404$ & $835 \pm 164$ & None & None & None & None \\
\hline
\end{tabular}

SEM, standard error of mean; E. coli, Escherichia coli; K. pneu, Klebsiella pneumonia; H. influ, Hemophilus influenzae; S. pneu, Streptococcus pneumonia; S. pyo, Streptococcus pyogenes; N. meni; Neisseria meningitidis.

in Fig. 2A, these effects persisted for 60 min compared to the control (distilled water spray).

Streptococcus pneumoniae. A total of $30 \mathrm{~min}$ after treatment with $0.0005 \mathrm{ppm}$ essential oils, colony growth decreased, but this was not observed after $60 \mathrm{~min}$. The essential oils decreased airborne bacterial colony growth in a dose-dependent manner. In the presence of 0.005 and 0.05 ppm essential oils, colony growth was significantly decreased at $20 \mathrm{~min}$. In addition, we observed little colony growth from air samples collected 20 min after treatment with 0.05 ppm essential oils (Fig. 2B).

Klebsiella pneumoniae. Colony growth decreased at $60 \mathrm{~min}$ following treatment with $0.0005 \mathrm{ppm}$ essential oils compared to the control. However, this decreased rate of colony growth was lower than that observed following treatment with higher concentrations of essential oils. After treatment with 0.005 and $0.05 \mathrm{ppm}$ essential oils, colony growth was suppressed at $30 \mathrm{~min}$ and $20 \mathrm{~min}$, respectively. Additionally, anti-airborne bacterial activities of essential oils (0.005 and $0.05 \mathrm{ppm})$ completely repressed the growth of colonies in essential oils (0.05 ppm) at $60 \mathrm{~min}$ (Fig. 2C).
Neisseria meningitidis. Following treatment with 0.0005 ppm essential oils, colony growth decreased at $30 \mathrm{~min}$, an effect that was observed at $60 \mathrm{~min}$. In the presence of 0.005 and $0.05 \mathrm{ppm}$ essential oils, growth of the colonies was decreased at $30 \mathrm{~min}$. Anti-airborne bacterial activities of essential oils (0.005 and $0.05 \mathrm{ppm}$ ) completely repressed colony growth at various concentrations of essential oils $(0.005$ and $0.05 \mathrm{ppm}$, and $0.005 \mathrm{ppm}$ ) at $40-60 \mathrm{~min}$, and $0.05 \mathrm{ppm}$ at 30-60 $\mathrm{min}$ (Fig. 2D).

Hemophilus influenzae. As shown in Fig. 2E, bacterial colony growth was not observed at $60 \mathrm{~min}$ for the control (distilled water spray). The lowest concentration of essential oils $(0.0005 \mathrm{ppm})$ inhibited the growth of colonies at $30-50 \mathrm{~min}$. In the presence of greater concentrations of essential oils (0.005 ppm and $0.05 \mathrm{ppm})$, colony growth was completely suppressed at 30-60 $\mathrm{min}$.

Escherichia coli. In the presence of essential oils (0.0005, 0.005 and $0.05 \mathrm{ppm}$ ), the growth of bacterial colonies was completely decreased at 60,30 and $20 \mathrm{~min}$, respectively. We did not observe colony growth after treatment with $0.05 \mathrm{ppm}$ essential oils at any time (Fig. 2F). 


\section{Discussion}

The walls of the bio-clean room were composed of non-interrupted acrylic plates, which are required for the successful aerosolization of bacterial cells. A Hypalon ${ }^{\circledR}$ glove attached to the front down panel of the bio-clean room protected the user's hands against the airborne bacterial cells. In this study, the effects of essential oils on airborne bacteria were examined in a bio-clean room. Essential oils, which are aromatic and volatile products of plant secondary metabolism, are widely used in folk medicine, food flavoring and preservation, and fragrances. The anti-bacterial activities of essential oils from various plants have been described by numerous studies (15-17).

Essential oils have been used medicinally $(18,19)$. The use of essential oils has been revived in the past few decades with the increasing popularity of aromatherapy, a branch of alternative medicine that claims that essential oils and other aromatic compounds have curative effects. The oils are distilled or volatilized in solutions and used for massages. Essential oils can also be dispersed into the air by a spray or heated over a candle flame for aromatherapy (20). In this study, we evaluated the anti-airborne bacterial activities of three concentrations of essential oils $(0.0005,0.005$ and $0.05 \mathrm{ppm})$ dispersed by artificial essential oil humidification on Gram-negative and -positive bacteria.

During the dry seasons, warm and humid environments affect the response of plasma pro- and anti-inflammatory cytokines (21). Dry eye is one of the most common pathological manifestations of chronic graft-versus-host disease, occurring in up to $80 \%$ of patients (22). Low or high humidity may cause specific physical discomfort since relative humidity directly affects temperature perception (23). Diseases may be transmitted by airborne pathogens, direct contact with pathogens living on hard surfaces or by touching an infected person. Low humidity has been found to improve the survival of rhinoviruses, influenza virus (24) and human rotavirus $(25,26)$. The incidence of airborne-transmitted infectious disease in an indoor environment is dependent on a number of factors, including the concentration of aerosolized pathogens, ventilation rate and survival of pathogens attached to the aerosol (20). The indoor relative humidity may affect some of these factors, including settling rate of the aerosols and survival of the airborne pathogens (27).

Patients and healthy individuals require optimal humidification to maintain a moisturized respiratory tract necessary for protection against bacterial infection during the drier winter months. However, humidifiers are associated with certain health risks. For example, the water tank and tract of humidifiers are easily polluted by airborne pathogens and allergens. Humidifier disinfectants have been regularly used to clean humidifiers. However, warnings about the health risks associated with humidifier disinfectants have been issued by the Korean Center for Disease Control and Prevention advising against the use of humidifier sterilizers. The notification was issued after a civic group claimed that 18 pregnant females succumbed to lung disease which was considered to have been caused by disinfectants in the machines.

The results from our study demonstrated that the growth of airborne bacterial cells decreased following exposure to three different concentrations of essential oils $(0.0005,0.005$ and $0.05 \mathrm{ppm}$ ) in a customized bio-clean room. It is possible that these essential oils may be used as anti-airborne bacterial agents, and humidifier disinfectants in commercial humidifiers and air cleaners. However, the mechanisms underlying the anti-airborne bacterial effects of essential oils require further examination.

\section{Acknowledgements}

This study was supported by a grant from the Woongjin and the Next-generation BioGreen 21 Program (No. PJ008323), Rural Development Administration, Republic of Korea.

\section{References}

1. Harkenthal M, Reichling J, Geiss HK and Saller R: Comparative study on the in vitro antibacterial activity of Australian tea tree oil, cajuput oil, niaouli oil, manuka oil, kanuka oil, and eucalyptus oil. Pharmazie 54: 460-463, 1999.

2. Carson CF, Cookson BD, Farrelly HD and Riley TV: Susceptibility of methicillin-resistant Staphylococcus aureus to the essential oil of Melaleuca alternifolia. J Antimicrob Chemother 35: 421-424, 1995.

3. Aziz NH, Farag SE, Mousa LA and Abo-Zaid MA: Comparative antibacterial and antifungal effects of some phenolic compounds. Microbios 93: 43-54, 1998.

4. Basaga H, Poli G, Tekkaya $\mathrm{C}$ and Aras I: Free radical scavenging and antioxidative properties of 'silibin' complexes on microsomal lipid peroxidation. Cell Biochem Funct 15: 27-33, 1997.

5. Jaime L, Mendiola JA, Herrero M, et al: Separation and characterization of antioxidants from Spirulina platensis microalga combining pressurized liquid extraction, TLC, and HPLC-DAD. J Sep Sci 28: 2111-2119, 2005.

6. Jones RC, Hughes CR, Wright D and Baumer JH: Early house moves, indoor air, heating methods and asthma. Respir Med 93: 919-922, 1999.

7. Vincent D, Annesi I, Festy B and Lambrozo J: Ventilation system, indoor air quality, and health outcomes in Parisian modern office workers. Environ Res 75: 100-112, 1997.

8. O'Connor GT: Allergen avoidance in asthma: what do we do now? J Allergy Clin Immunol 116: 26-30, 2005.

9. Vaughan JW, Woodfolk JA and Platts-Mills TA: Assessment of vacuum cleaners and vacuum cleaner bags recommended for allergic subjects. J Allergy Clin Immunol 104: 1079-1083, 1999.

10. Gore RB, Durrell B, Bishop S, Curbishley L, Woodcock A and Custovic A: High-efficiency particulate arrest-filter vacuum cleaners increase personal cat allergen exposure in homes with cats. J Allergy Clin Immunol 111: 784-787, 2003.

11. Haysom IW and Sharp K: The survival and recovery of bacteria in vacuum cleaner dust. J R Soc Promot Health 123: 39-45, 2003.

12. Shishido $H$, Nagai $H$ and Kawakami K: MRSA respiratory tract infection. Nihon Rinsho 50: 1075-1080, 1992.

13. Odagiri S: Respiratory tract infections caused by MRSA. Nihon Naika Gakkai Zasshi 81: 1620-1628, 1992.

14. Hogt AH, Dankert J and Feijen J: Adhesion of coagulase-negative staphylococci to methacrylate polymers and copolymers. J Biomed Mater Res 20: 533-545, 1986.

15. Hong EJ, Na KJ, Choi IG, Choi KC and Jeung EB: Antibacterial and antifungal effects of essential oils from coniferous trees. Biol Pharm Bull 27: 863-866, 2004.

16. Park MJ, Gwak KS, Yang I, et al: Antifungal activities of the essential oils in Syzygium aromaticum (L.) Merr. Et Perry and Leptospermum petersonii Bailey and their constituents against various dermatophytes. J Microbiol 45: 460-465, 2007.

17. Joo SS, Yoo YM, Ko SH, et al: Effects of essential oil from Chamaecypris obtusa on the development of atopic dermatitis-like skin lesions and the suppression of Th cytokines. J Dermatol Sci 60: 122-125,

18. Singh G, Kapoor IP, Pandey SK, Singh UK and Singh RK: Studies on essential oils: part 10; antibacterial activity of volatile oils of some spices. Phytother Res 16: 680-682, 2002. 
19. Prabuseenivasan S, Jayakumar $M$ and Ignacimuthu S: In vitro antibacterial activity of some plant essential oils. BMC Complement Altern Med 6: 39, 2006.

20. Hongratanaworakit T: Aroma-therapeutic effects of massage blended essential oils on humans. Nat Prod Commun 6: 1199-1204

21. Ng QY, Lee KW, Byrne C, Ho TF and Lim CL: Plasma endotoxin and immune responses during a 21-km road race under a warm and humid environment. Ann Acad Med Singapore 37: 307-314, 2008.

22. Ogawa Y, Kuwana M, Yamazaki K, et al: Dry eye associated with chronic graft-versus-host disease. Adv Exp Med Biol 506: 1041-1045, 2002.
23. No authors listed: Indoor air quality. Schriftenr Ver Wasser Boden Lufthyg 53: 1-439, 1982.

24. Buckland FE and Tyrrell DA: Loss of infectivity on drying various viruses. Nature 195: 1063-1064, 1962.

25. Moe K and Shirley JA: The effects of relative humidity and temperature on the survival of human rotavirus in faeces. Arch Virol 72: 179-186, 1982.

26. Couch RB: Viruses and indoor air pollution. Bull NY Acad Med 57: 907-921, 1981.

27. Arundel AV, Sterling EM, Biggin JH and Sterling TD: Indirect health effects of relative humidity in indoor environments. Environ Health Perspect 65: 351-361, 1986. 